\title{
Detrital tourmaline as an indicator of source rock lithology: an example from the Ropianka and Menilite formations (Skole Nappe, Polish Flysch Carpathians)
}

\author{
Dorota SALATA ${ }^{1, *}$ \\ 1 Institute of Geological Sciences, Jagiellonian University, Oleandry 2a, 30-063 Kraków, Poland
}

Salata D. (2014) Detrital tourmaline as an indicator of source rock lithology: an example from the Ropianka and Menilite formations (Skole Nappe, Polish Flysch Carpathians). Geological Quarterly, 58 (1): 19-30, doi: 10.7306/gq.1133

\begin{abstract}
Tourmaline populations studied from the Campanian-Maastrichtian part of the Ropianka (Upper Cretaceous-Paleocene) and Menilite (Oligocene) formations of the Polish Carpathians, represent a mixture of first-cycle and polycyclic grains. The tourmalines of the deposits studied display very strong resemblance in terms of optical features and chemical composition. They belong mostly to the schorl-dravite series with a minor contribution of tourmalines of foititic or Mg-foititic composition. Euhedral tourmalines originated from metasedimentary rocks, while the rounded grains crystallised in Li-poor granitic rocks or in pegmatites, Al-poor and Al-rich metasedimentary rocks. Most of the tourmalines studied crystallised during a single igneous or metamorphic event. However, tourmalines forming in evolving chemical conditions as well as polymetamorphic grains (having a metamorphic detrital core and metamorphic overgrowths) are also present. The chemical composition of the metamorphic tourmalines studied indicates their formation in medium-grade metamorphic conditions. This is supported by the crystallisation temperature of the garnet-biotite inclusion present in one of rounded metamorphic tourmalines from the Ropianka Formation. The euhedral grains derive from metasediments, directly from a massif located close to the Skole Ba$\sin$. The scarcity of euhedral grains in the tourmaline populations studied suggests that their source rocks were poor in these minerals. The direct sources of rounded tourmalines (most probably polycyclic grains), may have been Paleozoic and Mesozoic sedimentary rocks of the Skole Basin foreland or crystalline rocks of remote source areas. The initial igneous and metamorphic host rocks of the tourmalines may have been crystalline domains of the Bohemian Massif and/or the crystalline basement of Brunovistulicum.
\end{abstract}

Key words: detrital tourmaline, source rocks, Ropianka Fm., Menilite Fm., Skole Nappe, Outer Carpathians.

\section{INTRODUCTION}

Tourmaline is a mineral often found as a constituent of granites and associated pegmatites and regionally metamorphosed sedimentary rocks. However, it may be also a product of diagenetic processes (e.g., Henry and Guidotti, 1985; Henry and Dutrow, 1996; Dutrow and Henry, 2011 and references therein; Hinsberg et al., 2011a, b). Tourmaline is sensitive to physicochemical conditions in the host environment, reflecting these in its chemical composition. Due to its high resistance to weathering, mechanical abrasion and burial diagenesis, it preserves in the sedimentary environment, being able to survive multiple cycles of sedimentation (Morton and Hallsworth, 1999, 2007). The tourmaline crystallisation environment may be elucidated using data obtained by means of the commonly available electron microprobe. Igneous tourmaline can be discriminated from metasedimentary tourmaline by means of molecular proportions of Mg, Fe, Ca, and Al (Henry and Guidotti, 1985; Henry and Dutrow, 1996) and also of fluoride ions and lithium content

*E-mail: dorota.salata@uj.edu.pl

Received: August 9, 2013; accepted: September 27, 2013; first published online: November 21, 2013
(Henry and Dutrow, 1996). Therefore, tourmaline is a valuable mineral in source rock lithology determination, especially for heavy mineral assemblages of ancient or reworked sediments, usually depleted in highly diagnostic minerals, that are unstable during burial diagenesis (e.g., Morton and Hallsworth, 1999, 2007).

This study of tourmaline populations presents analytical data concerning this mineral in the Campanian-Maastrichtian part of the Ropianka Formation (Upper Cretaceous-Paleocene) and the Kliva and Boryslav sandstones of the Menilite Formation (Oligocene). Recent data concerning tourmalines from the Menilite Formation (Salata, 2013a) are supplemented with additional details and combined with new data on tourmalines from the Ropianka Formation. The current work is a compilation of analytical data and comparison of tourmaline occurring in heavy mineral assemblages of the parts of the Ropianka and Menilite formations studied. The data obtained enable determination of the source rock lithology of the tourmaline populations studied and shed more light on their source areas possible location and lithology.

\section{GEOLOGICAL SETTING AND SAMPLING}

The Skole Nappe is situated at the northeastern margin of the Outer Carpathians in Poland (Fig. 1A). It was a trough ini- 


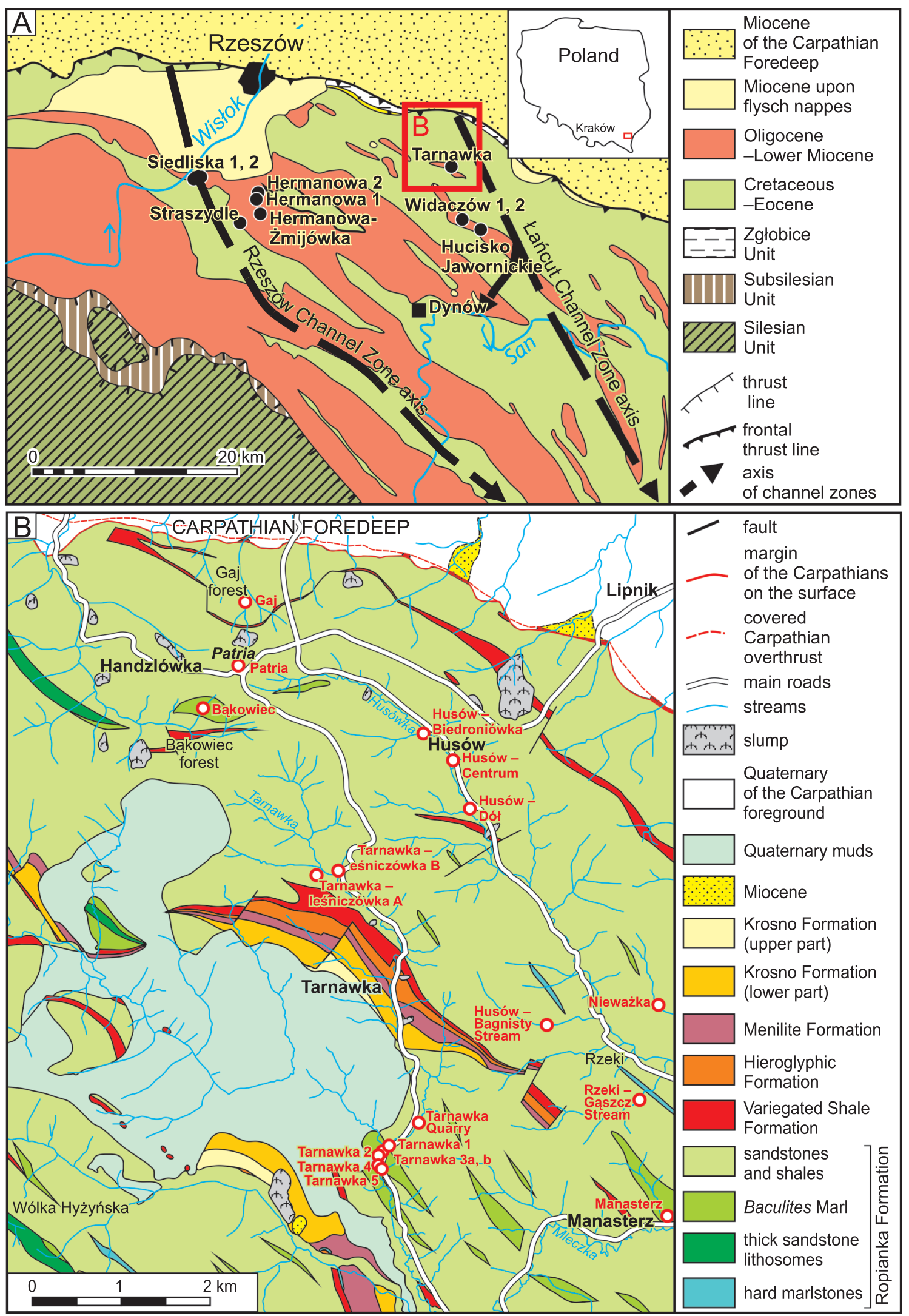

Fig. 1. Geological maps with location of the profiles sampled for heavy mineral analyses: A - sampled localities of the Boryslav and Kliva sandstones of the Menilite Formation (black circles); B - sampled localities of the Ropianka Formation sandstones (red circles) (Salata and Uchman, 2013; Salata, 2013c)

Part A based on Kotlarczyk and Leśniak (1990); part B based on Wdowiarz (1949) with modified descriptions of the lithostratigraphic units 
tially about $150 \mathrm{~km}$ wide (Gagała et al., 2012) that was bordered by the European Platform in the north and by the Subsilesian Ridge in the south (e.g., Ksiażkiewicz, 1962). The sediment fill of the basin was folded and thrusted northwards during the Miocene, and so the southern margin of the basin foreland lies now beneath the Carpathian nappes, unavailable for direct investigation. The palaeotransport directions show that the part of Skole Basin studied here was supplied mainly from the northwest during sedimentation of the Ropianka and Menilite formations (e.g., Książkiewicz, 1962; Kotlarczyk, 1966, 1976; Ślączka and Unrug, 1966; Bromowicz, 1974; Kotlarczyk and Leśniak, 1990). Sediments in these formations are believed to have been derived from the "Northern Marginal Cordillera" that was situated somewhere at the longitude of the present-day location of Tarnów (e.g., Książkiewicz, 1962; Unrug, 1979). Therefore, the areas of the Skole Nappe studied, south-east of Rzeszów and Łańcut (Fig. 1), represent regions located close to the southern margin of the Skole Basin foreland.

The Upper Cretaceous-Paleocene deposits of the Skole Nappe are distinguished as the Ropianka Formation (called also the Inoceramian Beds in the older literature; Kotlarczyk, 1978 and references therein). They are overlain by the upper Paleocene-Eocene mudstone-dominated Variegated Shale Formation and the Eocene Hieroglyphic Formation (Rajchel, 1990; Fig. 2). The deposits studied, sampled in the area SE of Łańcut, belong to the Wiar and Leszczyny members of the Ropianka Formation (Kotlarczyk, 1978), which were deposited by density-flow currents. The sandstone-dominated sections represent proximal parts of the depositional system (the channel facies of a submarine fan in the Manasterz, Husów - Patria, Husów - Biedroniówka, Nieważka sections) and more distal parts of the system (depositional lobes, interlobes or fan fringes in the Husów - Gaj, Husów - Bakowiec, Husów - Bagnisty Stream, Rzeki - Gąszcz Stream, Tarnawka - leśniczówka A, B, Tarnawka 1-5, Tarnawka Quarry sections; Fig. 1B; for details of sampled sections see Salata and Uchman, 2013). The sandstones of the Ropianka Formation, in the area studied, are quartz-dominated but they contain also feldspars, lithic fragments and subordinately mica, glauconite and coalified plant debris. Among the lithic fragments, limestones and siliceous rocks prevail. Additionally, igneous rocks, such as fine-grained granitoids, dacites, mica-schists and gneisses, are also present (e.g., Bromowicz, 1974, 1986 and references therein). The sandstones represent mainly fine- to medium-grained and wellto moderately-sorted sublitharenite and subordinate subarkose types (Bromowicz, 1974).

The Oligocene and Lower Miocene infill of the Skole Basin belongs to the Menilite and Krosno formations - the highest deposits of the sedimentary succession of the Skole Nappe (Kotlarczyk, 1966; Kotlarczyk and Leśniak, 1990). The characteristic rocks of the Menilite Formation are dark, black or brown shales, though thick sandstone units are also present (Fig. 2). Sandstones dominate in the Kliva and the Boryslav Sandstone members, which were deposited as gravity-driven flows, mainly in the Rzeszów and Łańcut channel zones, but the Kliva sandstone types may be also found outside them (Kotlarczyk and Leśniak, 1990). The sandstones for heavy mineral and the tourmalines analyses were sampled in the deposits of the northern parts of the channel zones (Fig. 1A; for details of sampled sections see Salata and Uchman, 2012). The Kliva and the Boryslav sandstone types are lithologically similar. They are quartzdominated, mostly fine- to medium-grained and well- to moderately-sorted. Quartz is accompanied by feldspars and muscovite, and in some places by glauconite. Among clasts, coal pieces, cherts and siltstones are common. The sandstones are poorly cemented, mostly massive, rarely laminated (e.g., Żgiet, 1963; Kotlarczyk, 1966, 1976; Ślączka and Unrug, 1966).

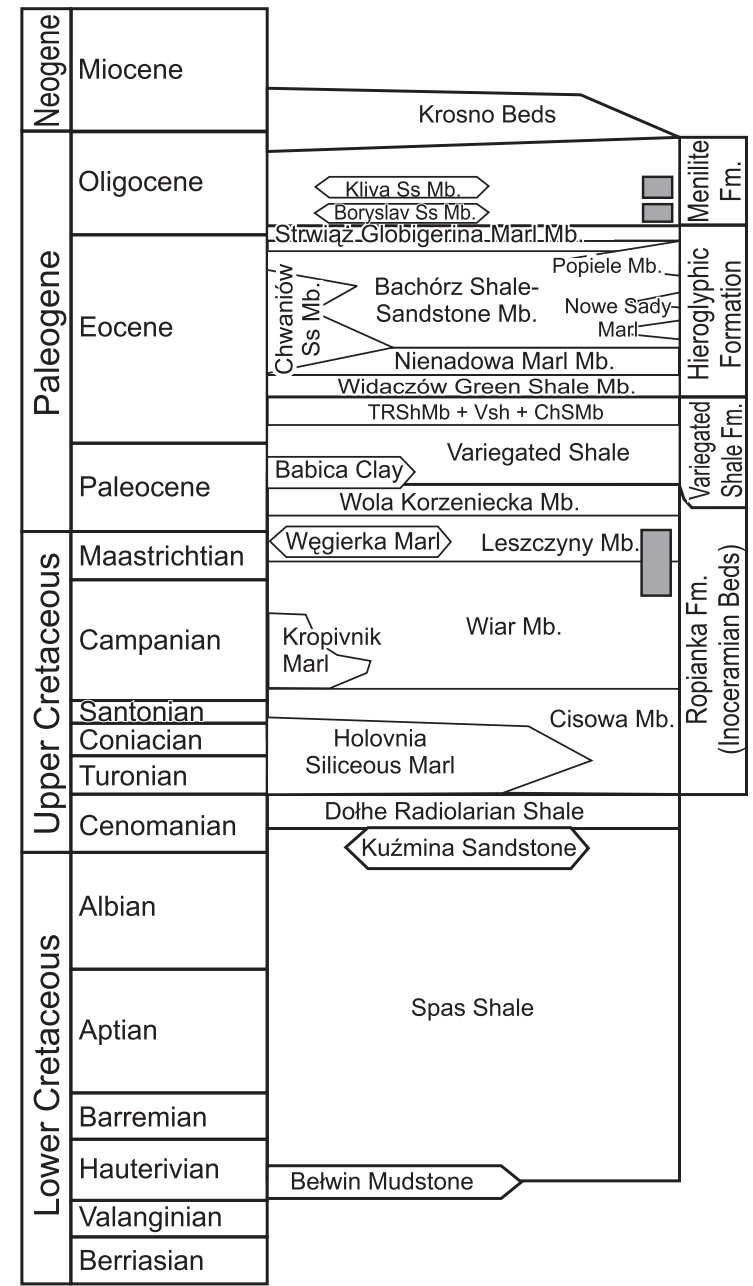

Fig. 2. Stratigraphic scheme of the Skole Nappe (based on Gasiński and Uchman, 2009 and references therein) with indication of the time-span intervals of the Ropianka and Menilite formations studied (grey rectangles)

Fm. - formation, Mb. - member, Ss - sandstone, TRShMb - Trójca Red Shale Member, VSh - Variegated Shale, $\mathrm{ChSMb}$ - Chmielnik Striped Sandstone Member

\section{ANALYTICAL METHODS}

The sandstones samples are weakly or very weakly consolidated rocks in both formations. Therefore, the preparatory procedure to heavy-mineral separation included only gentle disintegration and rinsing with water to clean off the clay fraction, followed by sieving to obtain the $63-250 \mu \mathrm{m}$ fraction. The heavy minerals were separated using the gravitational method in sodium polytungstate with a density of $2.9 \mathrm{~g} / \mathrm{cm}^{3}$. The separated heavy-mineral fraction was mounted in Canada balsam, and described and counted using a polarising optical microscope. In each sample, 200 to 300 grains of transparent, non-micaceous minerals were counted, according to the ribbon method (Galehouse, 1971). Mineral frequencies were calculated as number percentages (Salata and Uchman, 2012, 2013).

Observations in the microfield and identification of mineral inclusions in tourmaline grains were performed using a Hitachi S-4700 Field Emission Scanning Electron Microscope in the Laboratory of Field Emission Scanning Electron Microscopy and Microanalysis, at the Institute of Geological Sciences, Jagiellonian University, Kraków. The chemical composition of tourmalines, and garnet and biotite inclusions for thermometric 
data, was determined in carbon-coated, polished thin sections, using a Cameca SX-100 electron microprobe (EMP), operated in wavelength dispersion (WDS) mode, at the Joint-Institute Analytical Complex for Minerals and Synthetic Substances of Warsaw University. The WDS analytical conditions were as follows: $15 \mathrm{kV}$ accelerating voltage, $20 \mathrm{nA}$ beam current and a focused beam. The following, synthetic and natural, mineral standards were used for calibration: $\mathrm{Si}$ (wollastonite and diopside), $\mathrm{Al}$ and $\mathrm{K}$ (orthoclase), $\mathrm{Cr}\left(\mathrm{Cr}_{2} \mathrm{O}_{3}\right), \mathrm{Ti}$ (rutile), $\mathrm{Mg}$ (diopside), $\mathrm{Fe}$ $\left(\mathrm{Fe}_{2} \mathrm{O}_{3}\right), \mathrm{Mn}$ (rhodonite), $\mathrm{Ca}$ (diopside and wollastonite), $\mathrm{Na}$ (albite), F (phlogopite). Tourmalines were analysed using single-spots (one or two spots per grain) as well as along traverses. Tourmaline grains for single-spot microprobe analyses were chosen randomly for electron analyses. Tourmalines for traverse-analyses were handpicked under a stereomicroscope and arranged in rows. To check chemical inhomogeneity, preliminary traverse analyses were performed for tourmalines displaying visible changes in colour and those looking homogenous. Internal colour inhomogeneity, visible in transmitted light, was also reflected as darker or lighter zones in back-scattered electron images (BSE). Traverse analyses revealed that change in chemical composition was displayed only by tourmalines that were non-homogenous in terms of colour. Therefore, for homogenously-looking tourmalines only single or two-spot analyses were made. In total, microprobe analyses were made for 153 tourmaline grains in the Ropianka Formation and 123 grains in the Menilite Formation.

The amounts of $\mathrm{B}, \mathrm{H}$ and $\mathrm{Li}$ were not measured in the tourmalines. The contents of these elements were calculated using stoichiometric constraints, assuming $B=3$ apfu (atoms per formula unit), $\mathrm{OH}+\mathrm{F}=4$ apfu, $\mathrm{Li}=15-(\mathrm{T}+\mathrm{Z}+\mathrm{Y})$ and that all iron is $\mathrm{Fe}^{2+}$. The structural formula calculations were normalised to 31 anions. Although the calculation method ignores oxy-tourmaline species and means that the exact contents of non-measured elements and accordingly the calculated cation amounts are not precise (in particular $\mathrm{Li}_{2} \mathrm{O}$ and $\mathrm{H}_{2} \mathrm{O}$ amounts are likely overestimated), the results are sufficiently truthful for sedimentary provenance interpretations (e.g., Henry and Guidotti, 1985; Henry et al., 2011).

The garnet-biotite geothermometer of Holdaway (2000, 2004) was used to estimate the temperature of the garnet-biotite inclusion and its host tourmaline crystallisation.

\section{RESULTS}

\section{TOURMALINE CONTENT AND VARIETIES}

Tourmaline belongs among the main constituents of heavy mineral assemblages in the Ropianka and Menilite formations, comprising amounts of $19-31 \%$ and $20-35 \%$ respectively. To the remaining components, coexisting with tourmaline in the heavy mineral assemblages studied, belong zircon, rutile, garnet, staurolite, $\mathrm{Al}_{2} \mathrm{O}_{5}$ polymorphs (platy kyanite and less frequently andalusite; the latter detected only in the Menilite Formation), apatite, single grains of amphibole (found only in the Ropianka Formation), epidote and Cr-spinel. By comparison, the Ropianka Formation displays relatively higher amounts of zircon, garnet and apatite, while the Menilite Formation contains more kyanite and staurolite, whereas apatite is almost absent. The zircon-tourmaline-rutile index value (ZTR; Hubert, 1962) in both formations varies across a broad range comprising $27-95 \%$ and $29-55 \%$ in the Ropianka and Menilite formations respectively. Higher values of the ZTR index in the Ropianka Formation, in relation to the Menilite Formation, result mainly from elevated zircon frequencies (Salata and Uchman, 2012, 2013).
In the tourmaline populations studied, the same and comparable amounts of tourmaline varieties are present both in the Ropianka and Menilite formations. Considering the roundness degree, three types of grains were distinguished in both formations (Salata and Uchman, 2013):

- euhedral crystals or fragments of them (Fig. 3A, B);

- subrounded grains (Fig. 3C, D);

- highly rounded grains (Fig. 3E).

Among these, grains with smoothed surfaces (Fig. 3A-E), not displaying post-depositional diagenetic dissolution features, are most frequent, but highly corroded ones (Fig. 3F) may be also found. In terms of colour, brown and olive-brown, green, blue and pink varieties occur in both formations studied (Salata and Uchman, 2012, 2013). Rounded and subrounded brown tourmaline grains are dominant comprising $30-60 \%$ and $10-30 \%$ of tourmaline populations respectively. Amounts of rounded and subrounded green tourmaline reach $10 \%$, while pink and blue tourmaline is present rarely in individual samples, in amounts lower than $1 \%$. Among the angular and euhedral tourmaline group, brown varieties are most typical comprising up to $20 \%$, while green tourmaline is less frequent, occurring in amounts from 1 to $5 \%$. Angular tourmaline fragments and euhedral pink and blue tourmaline is very rare, less frequent than $1 \%$, and present only in a few samples (Salata and
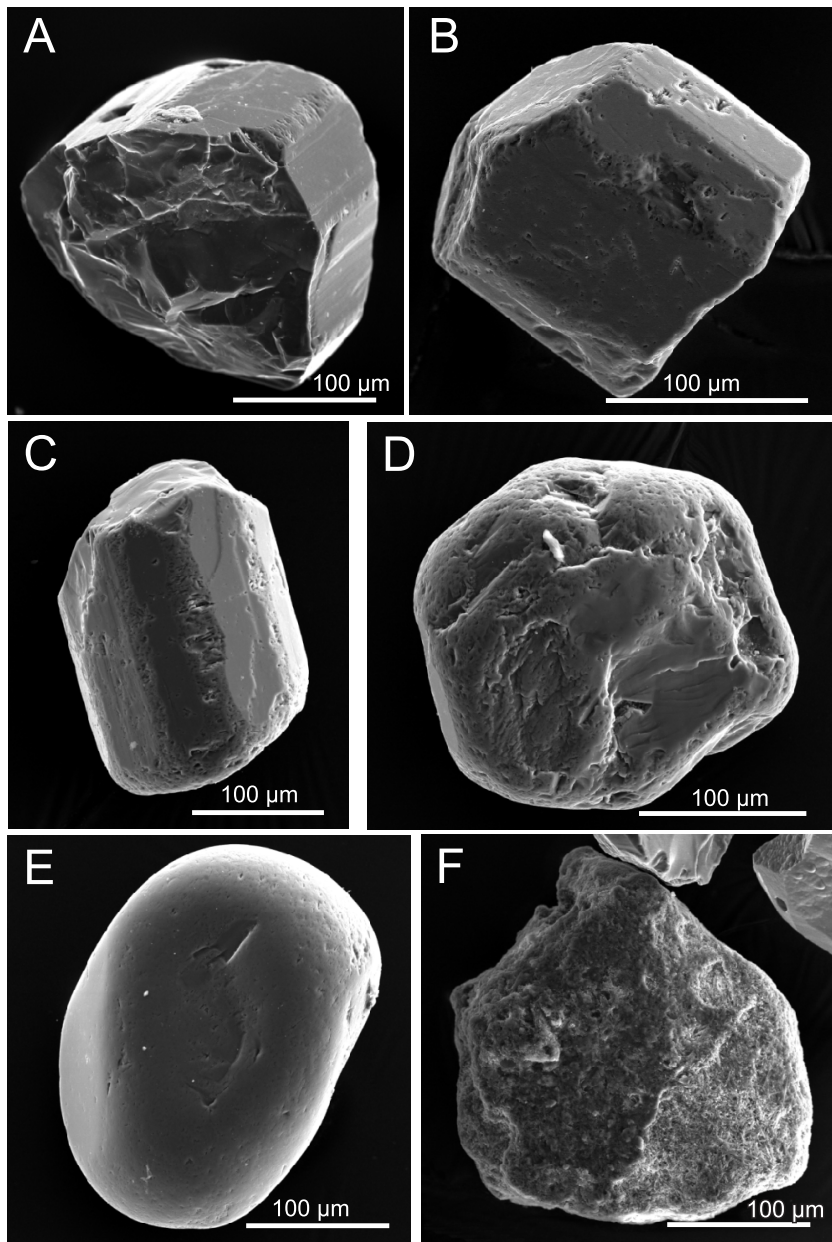

Fig. 3. Tourmaline types in terms of their roundness degree

SEM images: A, B - fragment of a euhedral crystal; $\mathbf{C}$ - fragment of a prism with moderately rounded edges; D - tourmaline prism with highly rounded edges but still distinguishable shape; $\mathbf{E}$ - highly rounded grain; $\mathbf{F}$ - piece of tourmaline with advanced corrosion microtextures 
Uchman, 2013). The tourmalines examined are mostly homogeneous in colour when seen in the transmitted light in Canada balsam. The inhomogeneous tourmalines display various colour zonation patterns ranging from very regular oscillatory to irregular and "patchy" (Fig. 4).

\section{TOURMALINE COMPOSITION}

The microprobe analyses have revealed that the chemical composition of the tourmalines analysed from the Ropianka and Menilite formations is very similar. The dominant cation occupying the X-site in the greater part of the tourmaline studied, both chemically homogeneous and zonal, is $\mathrm{Na}$, the amounts of which vary mostly in the range of $0.4-0.9$ apfu (Fig. 5 and Appendices $\left.1-3^{*}\right)$. The Ca content is usually lower than 0.2 apfu but over a dozen tourmalines of the Ropianka Formation display slightly elevated values, compared to the Menilite Formation, amounts of this element reaching up to 0.5 apfu (Fig. 5). The potassium content is subordinate, not exceeding 0.02 apfu. The tourmalines display $X$-site vacancy $\left(X_{v a c}\right)$ values generally lower than 0.5 , which enables one to classify them to the alkali primary group. Only few grains, with $\mathrm{X}_{\mathrm{vac}}$ slightly above 0.5 , belong to the X-vacant group (Fig. 5; Henry et al., 2011).

The dominant divalent cations in the $\mathrm{Y}$-site position of the tourmaline structure are $\mathrm{Fe}$ and $\mathrm{Mg}$, the amounts of which, and accordingly the $\mathrm{Mg} /(\mathrm{Mg}+\mathrm{Fe})$ ratio values, vary in a very broad range from nearly 0.0 to over 0.8 (Fig. 5 and Appendices 1-3). Therefore, most of the tourmaline represents the schorl-dravite series. The infrequent $\mathrm{Fe}$ - and Mg-rich tourmaline, with elevated Al contents, displays foititic and Mg-foititic composition respectively (Fig. 5 and Appendices 1-3). Such a composition was established in the population of homogeneous tourmaline and in zones of some zonal tourmalines (Fig. 6 and Appendices $1-3)$. The scarce euhedral tourmaline or grains with slightly rounded edges display dravitic composition or compositions changing from schorl in the central part to dravite in the rim (grains M_t3_rz1, R_t10_rz1, R_t12_rz1; Fig. 6 and Appendices 2,3$)$. The fluoride $\bar{i}$ ion, $\mathrm{Ti}^{-}$as well as the calculated $\mathrm{Li}$ amounts in all tourmalines are very low and do not exceed $0.3 \mathrm{apfu}$, while the remaining $\mathrm{Mn}$ and $\mathrm{Cr}$ contents mostly do not exceed 0.04 apfu (Appendices 1-3). The tetrahedral position is mostly fully occupied by $\mathrm{Si}$, while $\mathrm{Al}$, if present, is usually much lower than 0.2 apfu (Appendices 1-3).

The tourmaline that is homogeneous in colour does not display chemical zoning either, while in tourmaline that shows distinct changes of colour, fluctuations in $\mathrm{Fe}$ and $\mathrm{Mg}$ content and, less frequently, in $\mathrm{Ca}, \mathrm{Na}$ (Fig. 6 and Appendices 2, 3) or Al amounts (Appendices 2, 3), were observed. Such a change in the content of elements between colour zones often does not influence affiliation to a mineral species, even if the visual colour change between zones was pronounced (Figs. 4, 6 and Appendices 2, 3). However, in several grains, the composition of tourmaline changes through their cross-sections. In such cases, mainly schorl $\leftrightarrow$ dravite and less frequently schorl $\leftrightarrow$ foitite or combinations of schorl $\leftrightarrow$ foitite $\leftrightarrow$ dravite transitions were observed (Fig. 6 and Appendices 2, 3). Two grains, labelled R_t5_rz5 and R_t7_rz2 from the Ropianka Formation, seem to display complex structure with an older detrital core and subsequent rim (Fig. 4). The former grain displays dravitic composition in the core and schorlitic in the rim, while in the lat- ter grain the compositional change is reversed (Fig. 6 and Appendix 2).

The tourmaline studied contains numerous solid inclusions. To the most typical belong quartz, $\mathrm{TiO}_{2}$ polymorphs, zircon, biotite and monazite (Fig. 7A-D). Less frequently inclusions of Fe-oxides, apatite, pyrite, calcite, feldspar, titanite and garnet occur. An inclusion of coexisting almandine garnet and biotite (Appendix 4) was found in a certain tourmaline of dravitic composition (R_t13_rz3) in the Ropianka Formation (Fig. 7E). The crystallisation temperature of the garnet-biotite inclusion, estimated with the use of the garnet-biotite geothermometer of Holdaway $(2000,2004)$, was $511 \pm 20^{\circ} \mathrm{C}$ (Appendix 4).

\section{DISCUSSION OF TOURMALINE PROVENANCE}

\section{GENERAL REMARKS}

Chemical analyses revealed that granitic and metamorphic tourmalines occur in the tourmaline populations analysed (Fig. $8 \mathrm{~A})$, but the latter prevail in both formations. Granitic tourmalines comprise $41 \%$ and metamorphic tourmalines $59 \%$ of total tourmaline grains examined in the Ropianka Formation, whereas they comprise 38 and $62 \%$ in the Menilite Formation, respectively. The data show that the tourmalines originate from lithologically very similar source rock types. The igneous tourmalines represent Li-poor granites or associated pegmatite bodies, while the group of metamorphic tourmalines originate from $\mathrm{Al}$-poor and Al-rich metasedimentary rocks (Fig. 8A), as indicated by contents of $\mathrm{Al}, \mathrm{Fe}$ and $\mathrm{Mg}$. Additionally, the low contents of $A l$ in the T-sites and $X_{v a c}$ values ranging from 0.2-0.5 apfu, of tourmalines from both formations studied, plotting in the field of Al-rich metapelites, indicate their crystallisation below temperatures of about $700^{\circ} \mathrm{C}$ (Henry and Dutrow, 1996). This is supported by the crystallisation temperature calculated as $511 \pm 20^{\circ} \mathrm{C}$ of the garnet-biotite inclusion present in a metamorphic tourmaline grain from the Ropianka Formation (R_t13_rz3; Figs. 4, 7E and Appendix 4). Most of the chemically zoned metamorphic and igneous tourmalines appear to have formed during stable crystallisation conditions, as points denoting their composition plot close to each other in the environmental diagram (Fig. 8A). Only some points reflecting the chemistry of tourmalines and displaying distinct chemical change (mainly in the $\mathrm{Al}$ and less frequently in the $\mathrm{Mg}$ or Fe contents) plot in different fields of the provenance diagram (Fig. $8 \mathrm{~A})$. This may indicate that the crystallisation environment evolved during formation of the tourmalines, fingerprinting the tourmaline composition. Such a change in the tourmaline population of the Ropianka Formation was observed mainly for some metamorphic tourmalines, the discrimination points of which move between fields denoting Al-undersaturated and Al-saturated conditions (Fig. 8A). The situation is more complex for some tourmalines of the Menilite Formation, the chemistry of which suggests that their crystallisation conditions were changing between igneous and Al-undersaturated and Al-saturated metamorphic environments (grains M_t19_rz3, M_t9_rz3; Fig. $8 \mathrm{~A})$. The scarce euhedral grains analyse $\bar{d}$ in both formations originate from metapelites (Fig. 8A). The lack or very low content of tetrahedral $\mathrm{Al}$ and the $\mathrm{X}_{\mathrm{vac}}$ values ranging from 0.2-0.3 apfu (Appendices 2 and 3 ) suggest medium-grade

\footnotetext{
* Supplementary data associated with this article can be found, in the online version, at doi: $10.7306 / \mathrm{gq} .1133$
} 

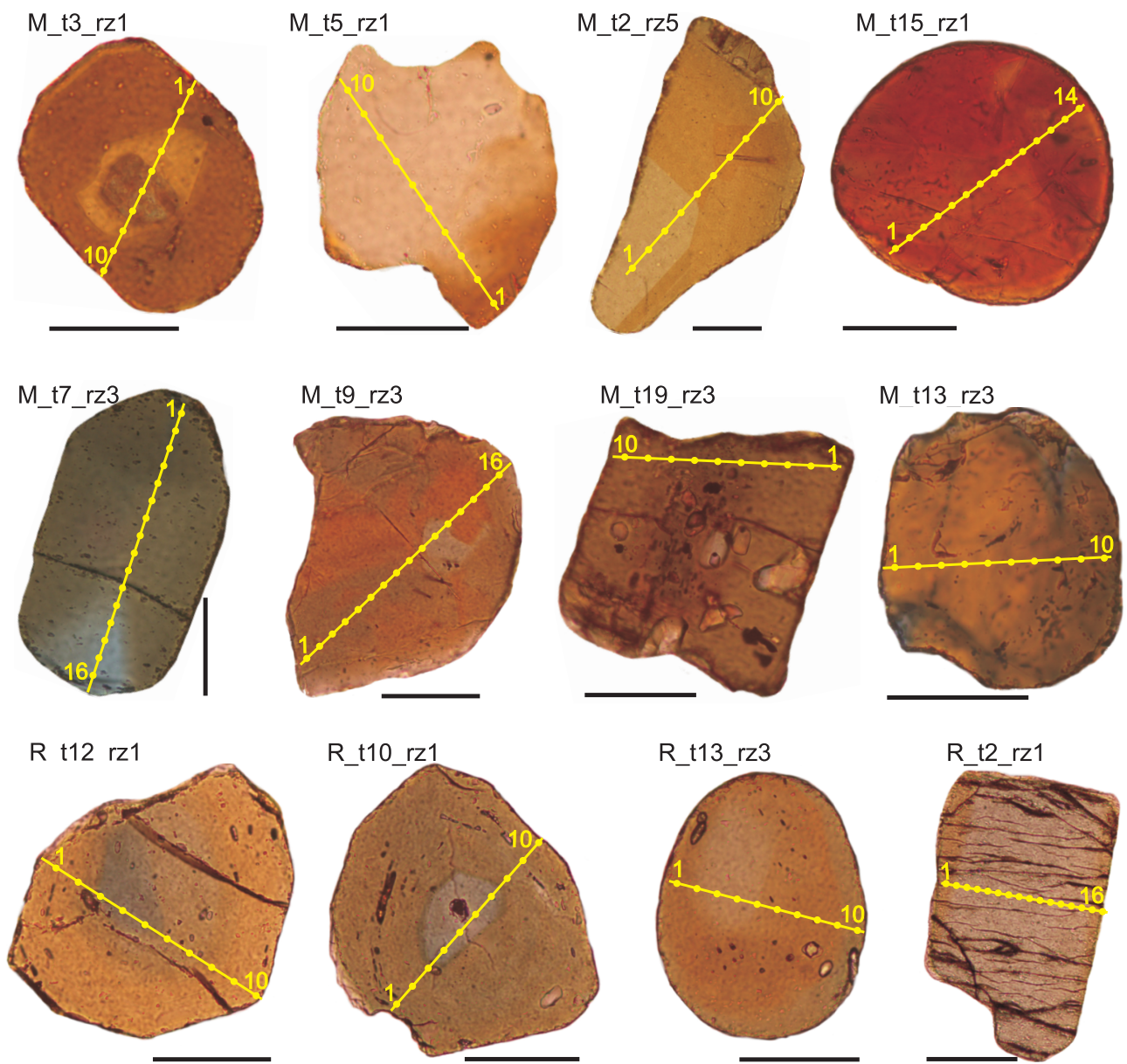

R_t13_rz3
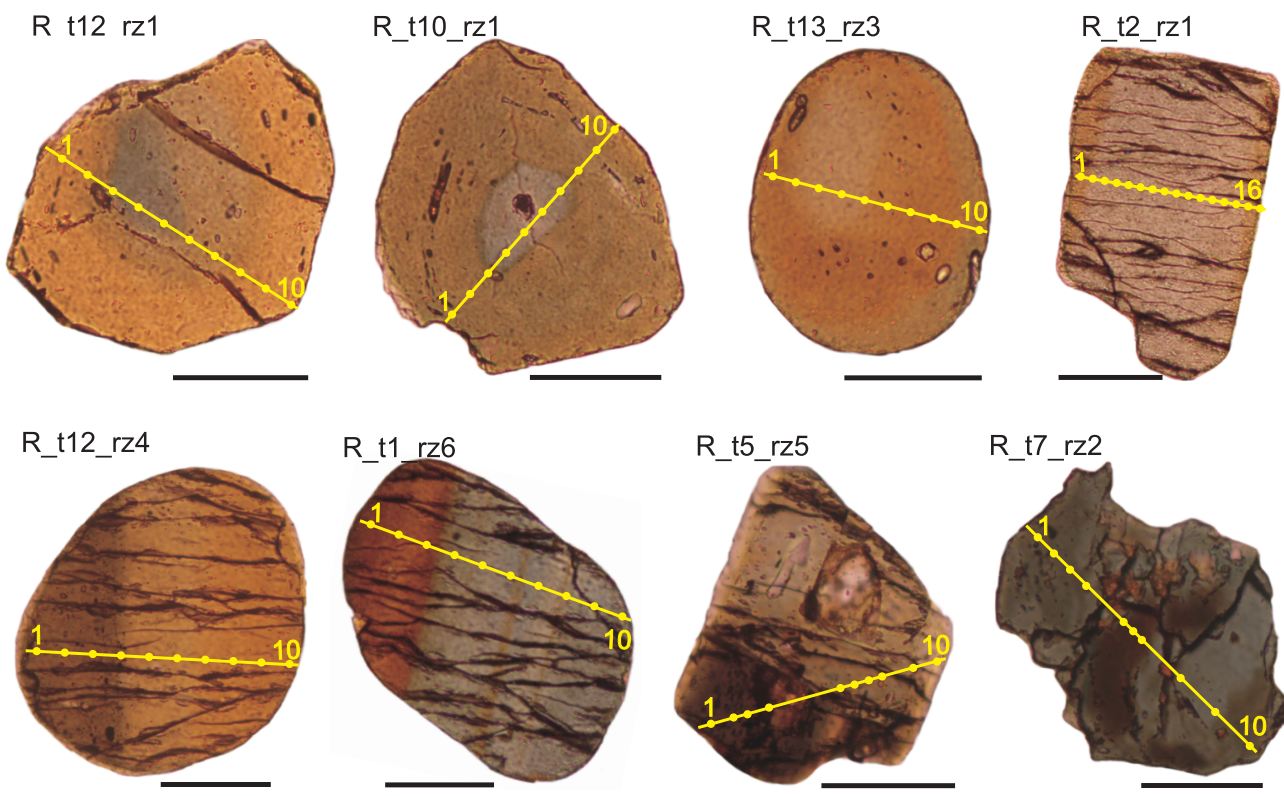

scale bar $=0.1 \mathrm{~mm}$

Fig. 4. Representative tourmaline grains of the Ropianka (grain labels start with R) and Menilite (grain labels start with M) formations showing typical colour and zonation patterns

Lines denote location of traverses during microprobe analyses and dots with numbers, stand for analytical spots; they correspond with the diagrams shown in Figure 6; thin section, plane-polarised light

metamorphic conditions during their crystallisation (Henry and Dutrow, 1996). The two grains from the Ropianka Formation that have detrital cores (R_t5_rz5, R_t7_rz2) display a similar provenance. Points denoting the chemistry of the detrital cores of these grains plot in the field of $\mathrm{Fe}^{3+}$-rich quartz-tourmaline rocks, calc-silicates and metapelites, while points denoting overgrowth composition are located in fields indicating provenance of the tourmalines from metapelites (Fig. 8A).

The coexistence of variously etched and highly rounded, subrounded and fresh euhedral grains suggests mixed first-cy- cle and polycyclic provenance of the tourmalines studied, thus their origin should be considered separately.

\section{EUHEDRAL TOURMALINE}

The scarce euhedral tourmalines most probably represent first-cycle delivery and come from a source massif located close to the Skole Basin. According to older literature (e.g., Książkiewicz, 1962; Unrug, 1979), during sedimentation of the 

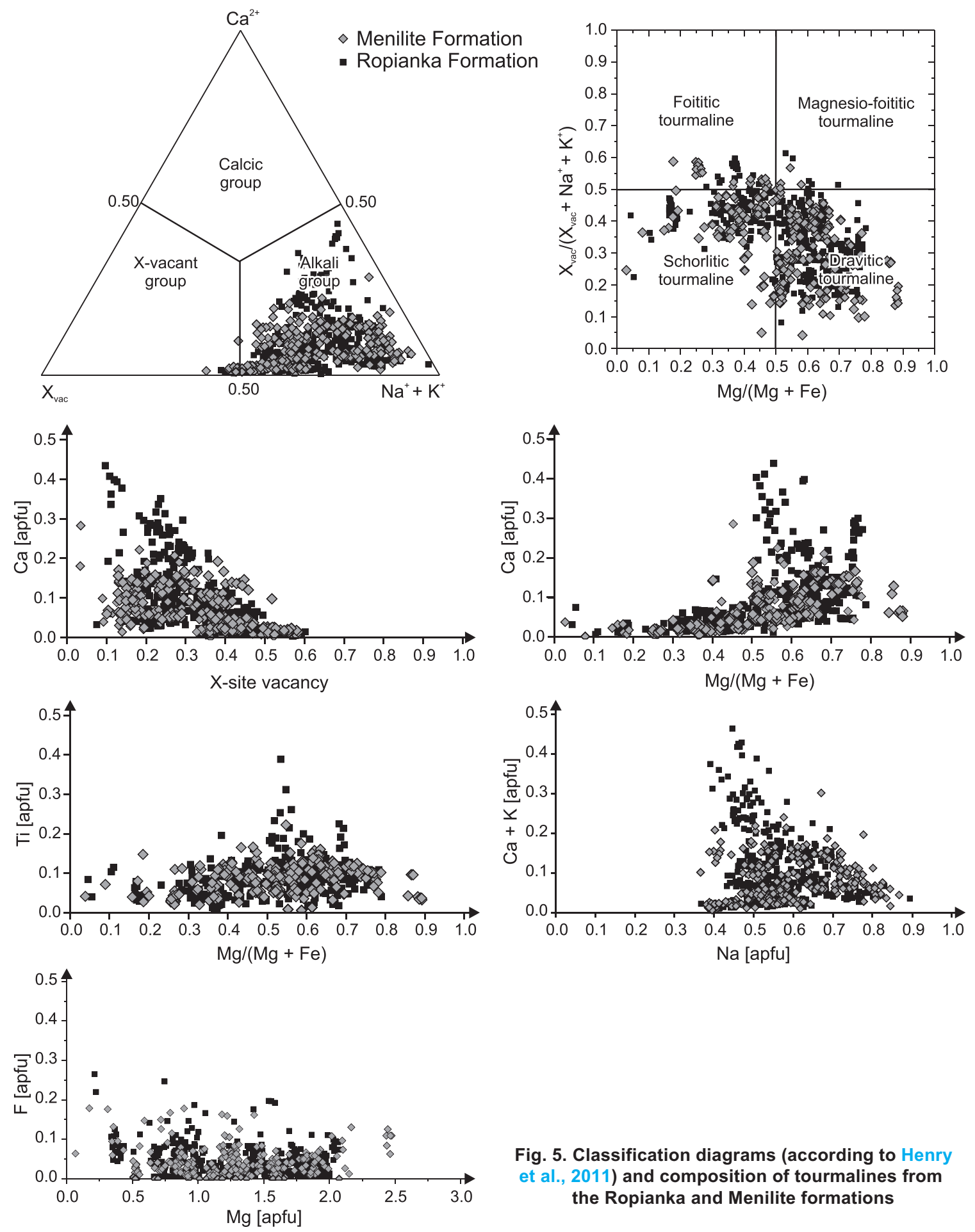

Fig. 5. Classification diagrams (according to Henry et al., 2011) and composition of tourmalines from the Ropianka and Menilite formations

Ropianka and Menilite formations in the area studied, such a massif, the "Northern Marginal Cordillera", was located in the northwestern margin of the basin, which is indicated by palaeotransport directions (e.g., Książkiewicz, 1962; Kotlarczyk, 1966, 1976; Ślączka and Unrug, 1966; Bromowicz, 1974; Kotlarczyk and Leśniak, 1990). The discovery of pebbles and clasts of gneiss and mica-schist in the Ropianka Formation, support the existence of potential source rocks for tourmalines in this source massif. However, the scarcity of euhedral tourmalines in the deposits studied suggests that the metamorphic source rocks building the cordillera were not rich in these minerals. Judging by the tourmaline composition, the same rocks may have been

a source for euhedral tourmalines of the Menilite Formation either. However, deposits of the Kliva and Boryslav sandstone members may represent, at least in part, palimpsest sediments sensu McManus (1975) (Salata and Uchman, 2013).

\section{ROUNDED TOURMALINE}

The question of provenance of the rounded tourmaline population is more complex. Tourmaline is highly resistant to both chemical weathering and transport processes, thus may survive long transportation over a few cycles of sedimentation. There- 

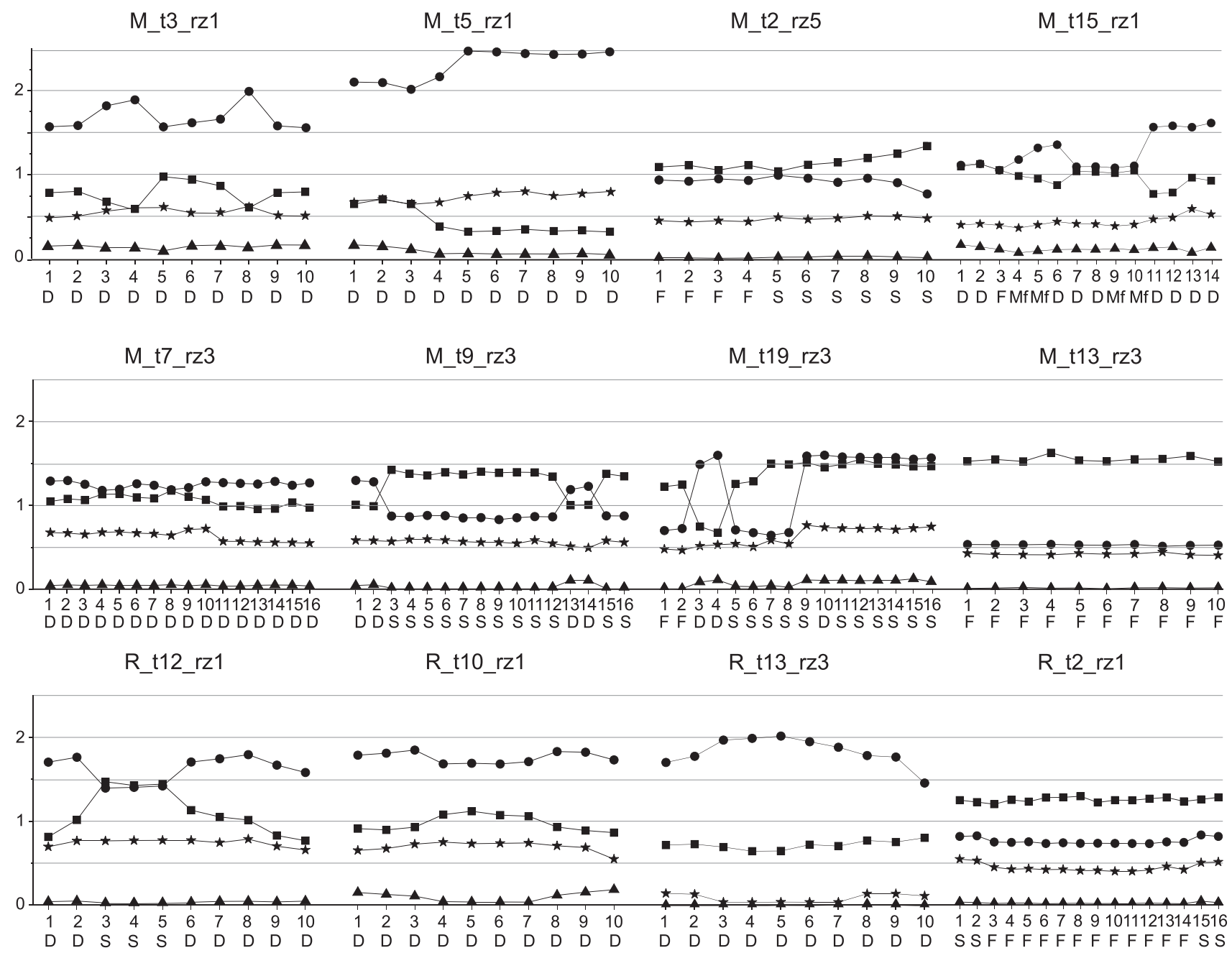

R_t12_rz4 R_t1_rz6 R_t5_rz5

R_t7_rz2

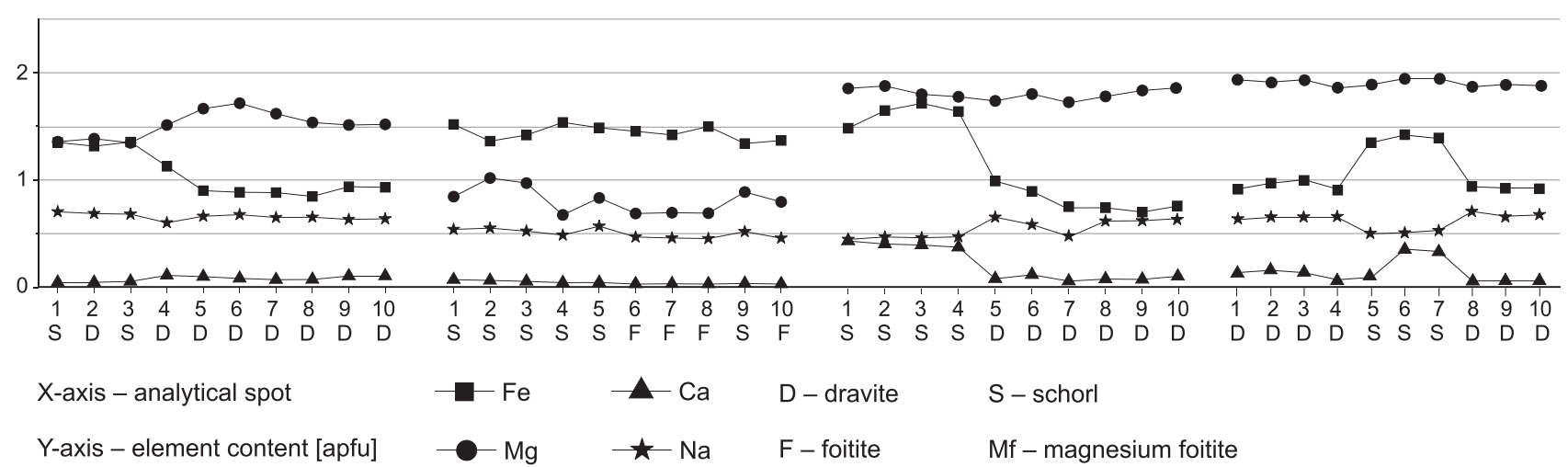

Fig. 6. Main element contents and compositional profiles along traverses in tourmaline grains shown in Figure 4

fore, the rounded tourmaline population may have been eroded from clastic rocks of the Skole Basin foreland or from metapsammites present in the "Northern Marginal Cordillera", in which rounded tourmaline would represent inherited primary detrital grains. However, in both these cases tourmaline represents polycyclic grains. Furthermore, the rounding may have been produced in coastal environments of the Skole Basin or during fluvial transportation from remote source areas. Nonetheless, the presence of Carboniferous coal clasts, and clasts of Mesozoic sedimentary rocks in deposits both of the Ropianka and Menilite formations (Wdowiarz, 1949; Kotlarczyk and Śliwowa, 1963; Nowak, 1963; Ślączka and Unrug, 1966; Bromowicz, 1974, 1986; Kotlarczyk, 1976; Rajchel and Myszkowska, 1998 and reference therein) support the idea of erosion of the sedimentary cover of the Skole Basin foreland during sedimentation of these formations. Taking into consideration the probable initial location of the Skole Basin (e.g., Golonka et al., 2006) and the subsequent rotation of the Carpathian orogen, the area studied may have been supplied from the sedimentary cover of the Małopolska Block and the eastern part of the Upper Silesian Block. 


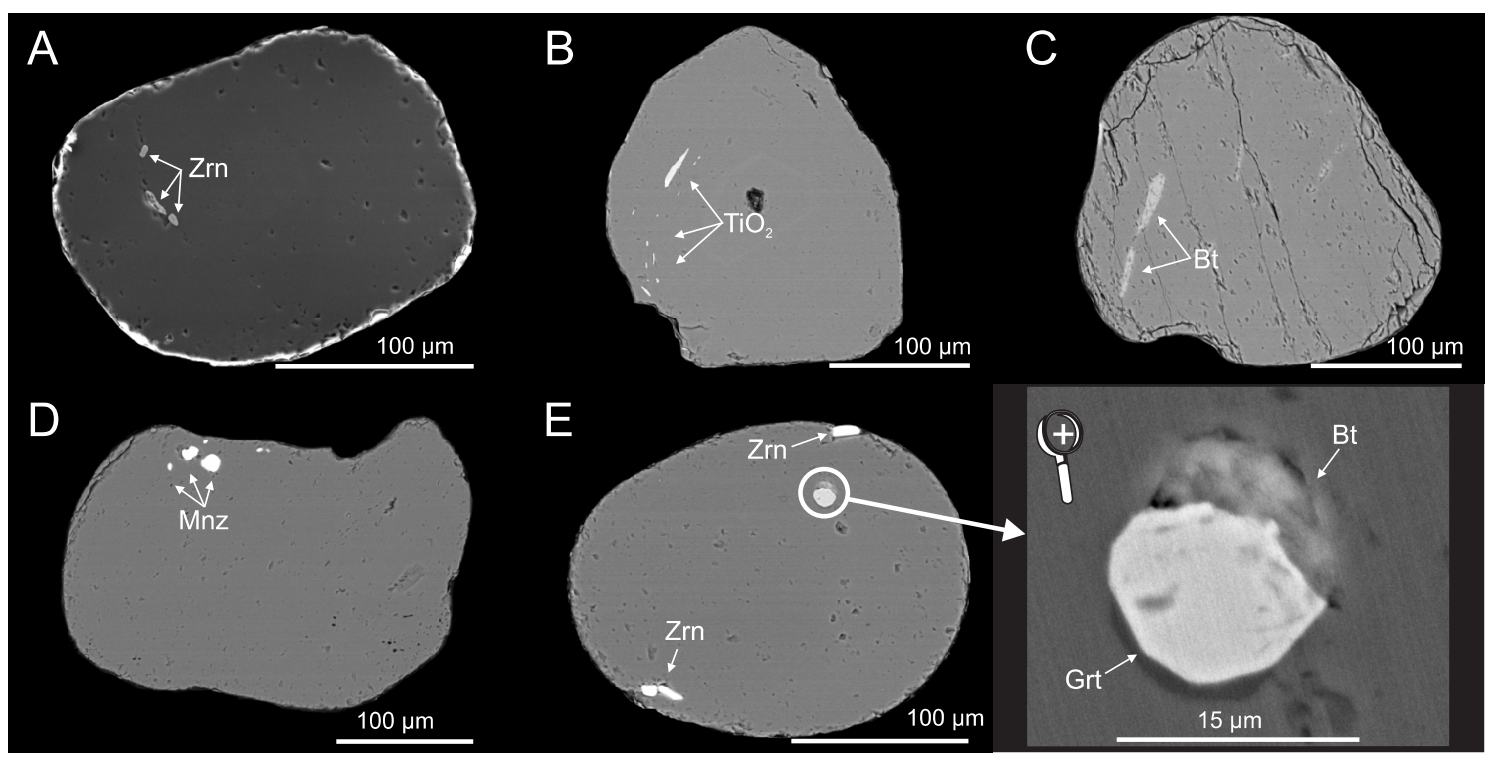

Fig. 7. Typical mineral inclusion types present in tourmalines from the formations studied

$\mathrm{Bt}$ - biotite, Grt - garnet, $\mathrm{Mnz}$ - monazite, $\mathrm{TiO}_{2}-\mathrm{TiO}_{2}$ polymorph, $\mathrm{Zrn}$ - zircon

Colour varieties of tourmalines occurring in the Upper Carboniferous and Middle Jurassic clastic deposits of the Upper Silesian and Małopolska blocks (e.g., Turnau-Morawska and Łydka, 1954; Łydka, 1955, 1958; Krysowska, 1959; Krysowska et al., 1960; Zachuń, 1996) and the chemical similarity of the tourmalines studied to those occurring in the clastic infill of the preCallovian Jurassic palaeokarst in the Kraków-Wieluń Upland (Fig. 8B; Salata, 2013b), provide further evidence reinforcing this idea. If the rounded tourmalines studied were derived from sedimentary or metasedimentary (as inherited grains) rocks, the question is where the protoliths, in which the tourmalines initially crystallised, were located. The high resistance of tourmalines allows a distant source area(s) for the rounded grains, but the same feature makes establishing the location of it (or them) difficult and uncertain. The possible sources are remote massifs of the Bohemian Massif and uplifted parts of the basement of Brunovistulicum (including the part of that currently under the Carpathians), which supplied Upper Carboniferous (e.g., Paszkowski et al., 1995) and Mesozoic (e.g., Salata, 2013a and references therein) clastic deposits of the Upper Silesian Block; the material could have been dispersed also on the Małopolska Block. A landmass located south of the Kraków-Wielun Upland was also suggested as a source for detrital garnet occurring in the Middle Jurassic clastic deposits of the Kraków area (Méres et al., 2012). The sedimentary rocks of the Upper Silesian and Małopolska blocks subsequently comprised sources of a clastic material deposited finally in the Skole Basin. However, tourmaline was not reported as a constituent of crystalline rocks building the basement of the Upper Silesian Block (e.g., Heflik and Konior, 1970, 1972, 1974; Górska and Heflik, 1975), but it cannot be excluded that tourmaline occurs in that part of it that was overthrusted by the Carpathians. By contrast, tourmaline is a common constituent of rock bodies in the Bohemian Massif, currently exposed and available for comparative studies. The rounded tourmalines studied display compositional resemblance to tourmalines occurring in various metamorphic and igneous bodies of the Moldanubian and Saxothuringian zones of the Bohemian Massif, including the Sudetic part of it (Fig. 8B; e.g., Pieczka, 1996; Burianek and Novák, 2004, 2007; Novák et al., 2004, 2013; Breiter et al., 2005; Słaby and Kozłowski, 2005;
Žáček and Sulovský, 2005; Novák, 2007; Čopjaková et al., 2009). The tourmalines studied are also alike in composition to detrital tourmalines shown to be derived mainly from the Bohemian Massif, occurring in deposits of the North Sudetic Synclinorium and Fore-Sudetic Homocline (Fig. 8B; Biernacka, 2012; Kowal-Linka and Stawikowski, 2013). Therefore, both the Bohemian Massif and a landmass(es) supplying the Carpathian basins foreland with clastic material are equally possible as sources, where the rounded tourmalines studied initially crystallised. The provenance of the two polymetamorphic grains from the Ropianka Formation ( $\left.R \_t 5 \_r z 5, R \_t 7 \_r z 2\right)$ is more complex. The metapelitic overgrowths of the tourmalines could have been formed in metamorphic complexes of the cordillera located in marginal parts of the Skole Basin, as the tourmalines are weakly rounded. The detrital cores (locating in the field of quartz-tourmaline rocks, calc-silicates or metapelites; Fig. 8A) of these two tourmalines may have the same type of protolith as some tourmalines from the Czatkowice palaeokarst infill (Salata, 2013a) or from redeposited tourmalinites from the Western Carpathians (Žáček et al., 2008 and references therein; Fig. 8B).

\section{CONCLUSIONS}

1. The detrital tourmalines, both euhedral and rounded, from the Ropianka and Menilite formations display very strong resemblance in terms of optical features and chemical composition. The tourmalines belong mostly to the schorl-dravite series with a minor contribution of tourmalines displaying foititic or Mg-foititic composition.

2. The chemical composition of the tourmalines studied indicates their crystallisation in Li-poor granitic rocks or pegmatites and $\mathrm{Al}$-poor and Al-rich metasedimentary rocks. Grains coming from metasedimentary rocks prevail in tourmaline populations of both the Ropianka and Menilite formations. Additionally, the low content of tetrahedral Al and X-vacancy values of tourmalines derived from Al-rich metapelites shows medium-grade metamorphic conditions of their formation. This is supported by the crystallisation temperature of the garnet-biotite inclusion, 

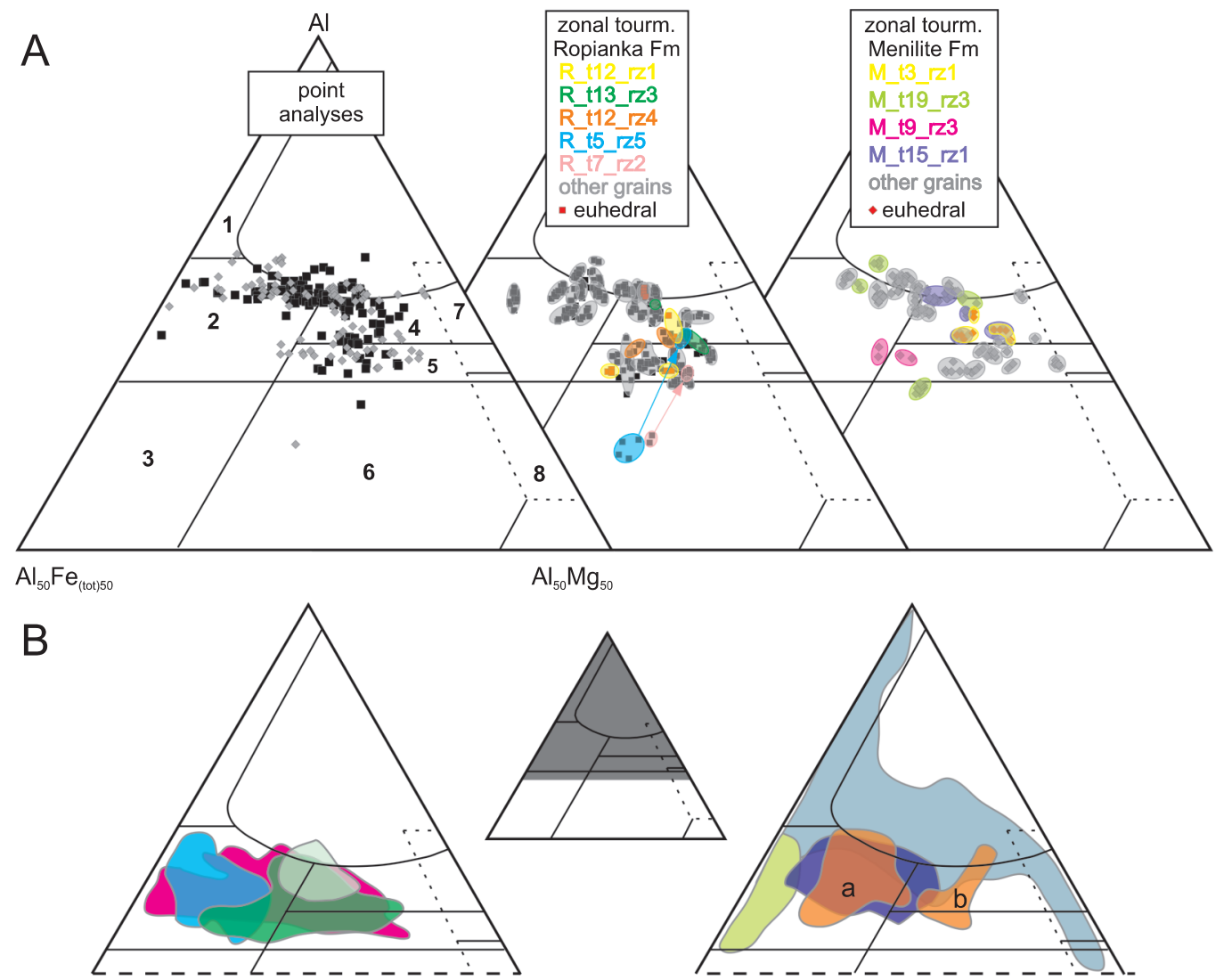

tourmalinites (Svratka Unit)

mica schists (Svratka Unit) orthogneiss (Moldanubicum)

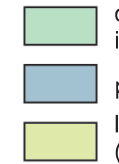

quartz-tourmalinie nodula in migmatite (Moldanubicum)

pegmatites (Moldanubicum)

leucogranite

(Saxothuringicum) leucocratic granite $(a)$

and hydrothermal veins (b)

(Moldanubicum)

leucogranites

(Moldanubicum)

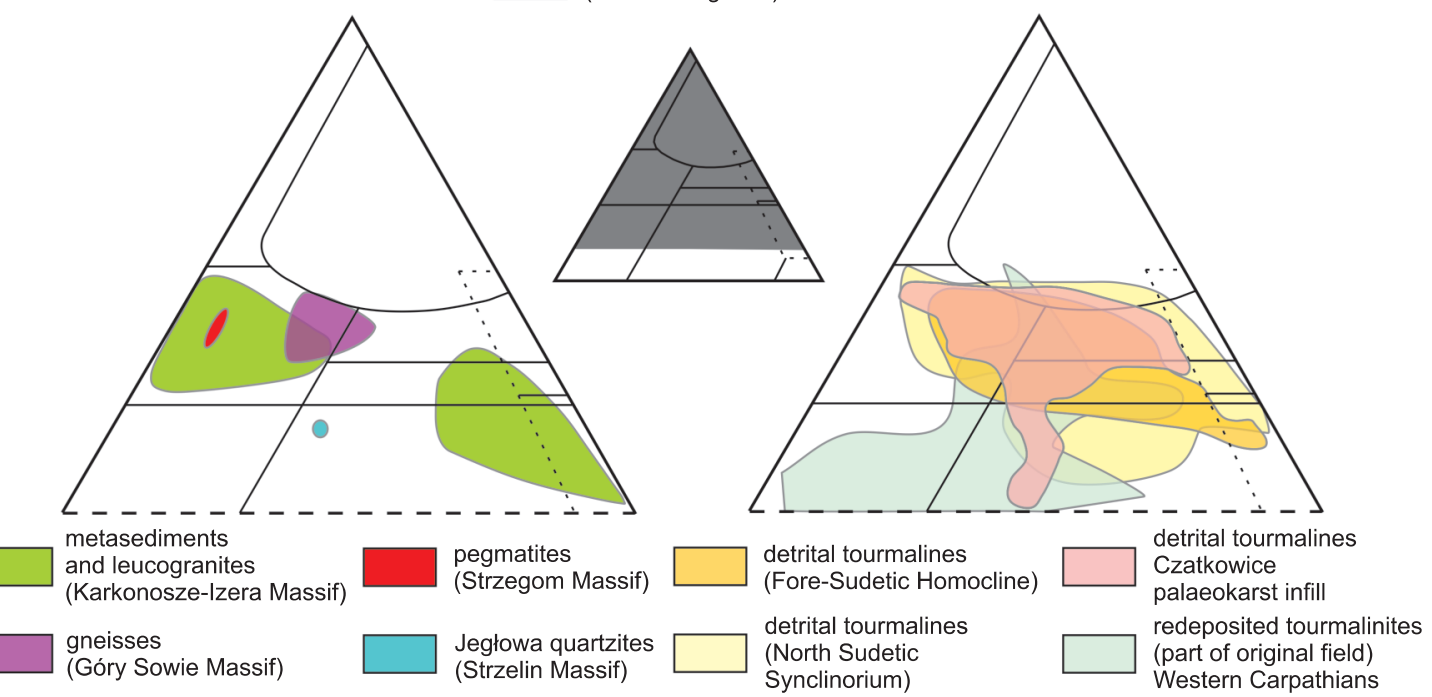

Fig. 8A- distribution of points reflecting compositions of the tourmalines studied on provenance diagrams of Henry and Guidotti (1985); coloured fields in diagrams of zonal tourmalines studied encircle all points measured in a certain tourmaline grain indicated; B - compositional fields of tourmalines from various rocks of the Bohemian Massif and detrital tourmalines reported as originating from crystalline domains of the massif. The numbered fields correspond to the following rock types: 1 - Li-rich granitoids, pegmatites and aplites; 2 Li-poor granitoids, pegmatites and aplites; 3 - hydrothermally altered, granitic rocks; 4 - Al-rich metapelites and metapsammites; 5 - Al-poor metapelites and metapsammites; $6-\mathrm{Fe}^{3+}$-rich quartz-tourmaline rocks, calcsilicates and metapelites; 7 - Ca-poor ultramafites; 8 - metacarbonates and metapyroxenites. Compositional fields in part B according to analytical data from: Pieczka, 1996; Burianek and Novák, 2004, 2007; Novák et al., 2004, 2013; Breiter et al., 2005; Słaby and Kozłowski, 2005; Bačík and Sulovský, 2005; Novák, 2007; Bačík et al., 2008; Čopjaková et al., 2009; Biernacka, 2012; Kowal-Linka and Stawikowski, 2013; Salata, 2013b). Explanation of symbols as in Figure 5 
present in a dravitic tourmaline grain from the Ropianka Formation. Furthermore, the tourmaline compositions indicates that most of them crystallised during a single stable igneous or metamorphic event. However, tourmalines formed in evolving chemical conditions as well as poly-metamorphic grains are also present.

3. Judging from the rounding, the tourmaline populations studied represent a mixture of first-cycle and polycyclic grains. Euhedral tourmalines representing the first-cycle delivery are metasedimentary in origin and are derived from a source located near to the Skole Basin (e.g., the "Northern Marginal Cordillera"). The scarcity of euhedral grains in the tourmaline populations studied suggests that the source rocks were poor in these minerals. The parent igneous and metamorphic rocks of the rounded tourmalines may have been crystalline domains of the Bohemian Massif and/or the crystalline basement of Brunovistulicum. The sources initially supplied Upper Paleozoic and partly Mesozoic clastic sediments deposited on the Upper Silesia and Małopolska blocks, which became the ultimate sources for the clastic material forming sandstones of the Ropianka and Menilite formations.

Acknowledgments. I am grateful to the reviewers: M. Novák (Masaryk University) and J. Rajchel (AGH University of Science and Technology) for their constructive remarks and comments, which helped to improve the manuscript. The author is also indebted to L. Jeżak and P. Dzierżanowski (Warsaw University) for their assistance in EMPA analyses. The study was financed by the Jagiellonian University and partly supported by the NCN grant 2013/09/B/ST10/00591.

\section{REFERENCES}

Bačík P., Uher P., Sýkora M., Lipka J. (2008) Low-Al tourmalines of the schorl-dravite-povondraite series in redeposited tourmalinites from the Western Carpathians, Slovakia. Canadian Mineralogist, 46: 1117-1129.

Biernacka J. (2012) Provenance of Upper Cretaceous quartz-rich sandstones from the North Sudetic Synclinorium, SW Poland: constraints from detrital tourmaline. Geological Quarterly, 56 (2): 315-332.

Breiter K., Čopjaková R., Gabašova A., Škoda R. (2005) Chemistry and mineralogy of orthogneiss in the northeastern part of Moldanubicum. Journal of the Czech Geological Society, 50: 81-94.

Bromowicz J. (1974) Facial variability and lithological character of Inoceramian Beds of the Skole Nappe between Rzeszów and Przemyśl (in Polish with English summary). Prace Geologiczne, 84: 1-81.

Bromowicz J. (1986) Petrographic differentiation of source areas of Ropianka Beds east of Dunajec River (Outer Carpathians, Poland) (in Polish with English summary). Annales Societatis Geologorum Poloniae, 56: 253-276.

Buriánek D., Novák M. (2004) Morphological and mineralogical evolution of tourmaline from nodular granite at Lavičky near Velké Meziričci, Moldanubicum, Czech Republic. Journal of the Czech Geological Society, 49: 81-90.

Buriánek D., Novák M. (2007) Compositional evolution and substitutions in disseminated and nodular tourmaline from leucocratic granites: Examples from the Bohemian Massif, Czech Republic. Lithos, 95: 148-164.

Čopjaková R., Buriánek D., Škoda R., Houzar S. (2009) Tourmalinites in the metamorphic complex of the Svratka Unit (Bohemian Massif): a study of compositional growth of tourmaline and genetic relations. Journal of Geosciences, 54: 221-243.

Dutrow B.L., Henry D.J. (2011) Tourmaline: a geologic DVD. Elements, 7: 301-306.

Galehouse J.S. (1971) Point Counting. In: Procedures in Sedimentary Petrology (ed. R.E. Carver): 385-407. Wiley Interscience, New York.

Gasiński M.A., Uchman A. (2009) Latest Maastrichtian foraminiferal assemblages from the Husów region (Skole Nappe, Outer Carpathians, Poland). Geologica Carpathica, 60: 283-294.

Gągała Ł., Vergés J., Saura E., Malata T., Ringenbach J.C., Werner P., Krzywiec P. (2012) Architecture and orogenic evolution of the north-eastern Outer Carpathians from cross-section balancing and forward modelling. Tectonophysics, 532-535: 223-241.

Golonka J., Krobicki M., Oszczypko N., Ślączka A. (2006) Palinspastic modelling and Carpathian Phanerozoic palaeogeographic maps (in Polish with English summary). In: Palaeo- tectonic Evolution of the Outer Carpathian and Pieniny Klippen Belt Basins (eds. N. Oszczpko, A. Uchman and E. Malata): 103-110. Instytut Nauk Geologicznych Uniwersytetu Jagiellońskiego, Kraków.

Górska L., Heflik W. (1975) Hornblende-epidote schists and amphibolites from crystalline basement of the Cieszyn-Kraków area (in Polish with English summary). Geologia, 1: 41-47.

Heflik W., Konior K. (1970) Granitoids in the sub-Devonian basement of the Bielsko-Andrychów area (in Polish with English summary). Kwartalnik Geologiczny, 14 (2): 283-289.

Heflik W., Konior K. (1972) Metamorphic formations in borehole Dobczyce 1 (in Polish with English summary). Kwartalnik Geologiczny, 16 (3): 546-556.

Heflik W., Konior K. (1974) The present state of knowledge concerning the crystalline basement in the Cieszyn-Rzeszotary area (in Polish with English summary). Biuletyn Instytutu Geologicznego, 273: 195-221.

Henry D.J., Guidotti C.V. (1985) Tourmaline as a petrogenetic indicator mineral: an example from the staurolite-grade metapelites of NW Maine. American Mineralogist, 70: 1-15.

Henry D.J., Dutrow B.L. (1996) Metamorphic tourmaline and its petrologic applications. Reviews in Mineralogy, 33: 503-557.

Henry D.J., Novák M., Hawthorne F.C., Ertl A., Dutrow B.L., Uher P., Pezzotta F. (2011) Nomenclature of the tourmalinesupergroup minerals. American Mineralogist, 96: 895-913.

Hinsberg V.J. van, Henry D.J., Dutrow B.L. (2011a) Tourmaline as a petrologic forensic mineral: a unique recorder of its geologic past. Elements, 7: 327-332.

Hinsberg V.J. van, Henry D.J., Marschall H.R. (2011b) Tourmaline: an ideal indicator of its host environment. Canadian Mineralogist, 49: 1-16.

Holdaway M.J. (2000) Application of new experimental and garnet Margules data to the garnet-biotite geothermometer. American Mineralogist, 85: 881-892.

Holdaway M.J. (2004) Optimization of some key geothermobarometers for pelitic metamorphic rocks. Mineralogical Magazine, 68: $1-14$.

Hubert J.F. (1962) A zircon-tourmaline maturity index and the interdependence of the composition of heavy mineral assemblages with the gross composition and texture of sandstones. Journal of Sedimentary Petrology, 32: 440-450.

Kotlarczyk J. (1966) Diatomite horizon of the Krosno Beds in the Skole Nappe, Polish Carpathians (in Polish with English summary). Studia Geologica Polonica, 19: 110-129.

Kotlarczyk J. (1976) Przyczynki do wyjaśnienia genezy piaskowców kliwskich w Karpatach Polskich (in Polish). Sprawozdania z Posiedzeń Komisji Naukowej PAN, Kraków, 19: 185-187. 
Kotlarczyk J. (1978) Stratigraphy of the Ropianka Formation or of Inoceramian beds in the Skole Unit of the Flysch Carpathians (in Polish with English summary). Prace Geologiczne, 108: 1-81.

Kotlarczyk J., Śliwowa M. (1963) On knowledge of the productive Carboniferous formations in the substratum of the eastern part of the Polish Carpathians (in Polish with English summary). Przegląd Geologiczny, 11: 268-272.

Kotlarczyk J., Leśniak T. (1990) Lower part of the Menilite Formation and related Futoma Diatomite Member in the Skole Unit of the Polish Carpathians (in Polish with English summary). Wydawnictwo Akademii Górniczo-Hutniczej, Kraków.

Kowal-Linka M., Stawikowski W. (2013) Garnet and tourmaline as provenance indicators of terrigenous material in epicontinental carbonates (Middle Triassic, S Poland). Sedimentary Geology, 291: $27-47$

Krysowska M. (1959) Assemblages of heavy minerals in Carboniferous sediments perforated at Bolesław near Olkusz (Upper Silesian Coal Basin) (in Polish with English summary). KwartaInik Geologiczny, 3 (4): 857-868.

Krysowska M., Piłat T., Wrochniak-Stopka W. (1960) Mineralogical-petrographical characteristic of the sediments of the highest Carboniferous at Płaza near Chrzanów (Cracow Region) (in Polish with English summary). Kwartalnik Geologiczny, 4 (2): 367-385.

Ksiażkiewicz M., ed. (1962) Geological Atlas of Poland. Fascicle 13 - Cretaceous and Early Tertiary in the Polish External Carpathians. Instytut Geologiczny, Warszawa.

Łydka K. (1955) Petrographic studies concerning the Permo-Carboniferous of the Cracow region (in Polish with English summary). Biuletyn Instytutu Geologicznego, 97: 123-215.

Łydka K. (1958) Petrography of Dogger in the profile of the borehole near Mielec (in Polish with English summary). Archiwum Mineralogiczne, 22: 187-205.

McManus D. (1975) Modern versus relict sediment on the continental shelf. GSA Bulletin, 86: 1154-1160.

Méres Š., Aubrecht R., Gradziński M., Sýkora M. (2012) High (ultrahigh) pressure metamorphic terrane rocks as the source of the detrital garnets from the Middle Jurassic sands and sandstones of the Cracow Region (Cracow-Wieluń Upland, Poland). Acta Geologica Polonica, 62: 231-245.

Morton A.C., Hallsworth C.R. (1999) Processes controlling the composition of heavy mineral assemblages in sandstones. Sedimentary Geology, 124: 3-29.

Morton A.C., Hallsworth C.R. (2007) Stability of detrital heavy minerals during burial diagenesis. Developments in Sedimentology, 58: $215-245$.

Novák M. (2007) Contamination in granitic pegmatites; examples from the Moldanubicum, Czech Republic. In: Granitic Pegmatites: the State of the Art (eds. T. Martins and R. Vieira): 9-12. International Symposium, Porto, Portugal, Book of Abstracts. Departamento de Geologia, Faculdade de Ciências, Universidade do Porto.

Novák M., Povondra P., Selway J.B. (2004) Schorl-oxy-schorl to dravite-oxy-dravite tourmaline from granitic pegmatites; examples from the Moldanubicum, Czech Republic. European Journal of Mineralogy, 16: 323-333.

Novák M., Kadlec T., Gadas P. (2013). Geological position, mineral assemblages and contamination of granitic pegmatites in the Moldanubian Zone, Czech Republic; examples from the Vlastějovice region. Journal of Geosciences, 58: 21-47.

Nowak W. (1963) Preliminary results of study on exotics from the Inoceramian Beds of the Skole series, of several sites in the Przemyśl and the Bircza Carpathians (in Polish with English summary). Kwartalnik Geologiczny, 7 (3): 421-430.
Paszkowski M., Jachowicz M., Michalik M., Teller L., Uchman A. Urbanek Z. (1995) Composition, age and provenance of gravel - sized clasts from the Upper Carboniferous of the Upper Silesia Coal Basin. Studia Geologica Polonica, 108: 45-127.

Pieczka A. (1996) Mineralogical study of Polish tourmalines (in Polish with English summary). Prace Mineralogiczne, 85: 1-79.

Rajchel J. (1990) Lithostratigraphy of the Upper Paleocene and Eocene sediments from the Skole Unit (in Polish with English summary). Zeszyty Naukowe AGH, Geologia, 48: 1-112.

Rajchel J., Myszkowska J. (1998) Exotic clasts of organodetritic algal limestones from lithosomes of the Babica Clay, Skole Unit (Outer Flysch Carpathians, Poland). Annales Societatis Geologorum Poloniae, 68: 225-235.

Salata D. (2013a) Source rocks for heavy minerals in lower part of Menilite Formation of Skole Nappe (Polish Flysch Carpathians), based on study of detrital garnet and tourmaline. Annales Societatis Geologorum Poloniae, 83: 1-17.

Salata D. (2013b) Heavy minerals as detritus provenance indicators for the Jurassic pre-Callovian palaeokarst infill from the Czatkowice quarry (Kraków-Wieluń Upland, Poland). Geological Quarterly, 57 (3): 537-550.

Salata D. (2013c) Garnet provenance in mixed first-cycle and polycycle heavy-mineral assemblages of the Ropianka and Menilite formations (Skole Nappe, Polish Flysch Carpathians): constraints from chemical composition and grain morphology. Annales Societatis Geologorum Poloniae, 83: 161-177.

Salata D., Uchman A. (2012) Heavy minerals from the Oligocene sandstones of the Menilite Formation of the Skole Nappe, SE Poland: a tool for provenance specification. Geological Quarterly, 56 (4): 803-820.

Salata D., Uchman A. (2013) Conventional and high-resolution heavy mineral analyses applied to flysch deposits: comparative provenance studies of the Ropianka (Upper Cretaceous-Palaeocene) and Menilite (Oligocene) formations (Skole Nappe, Polish Carpathians). Geological Quarterly, 57 (4): 649-664.

Słaby E., Kozłowski A. (2005) Composition of tourmalines from tin-tungsten-bearing country rock of the Variscan Karkonosze granitoid - a record of the wall rock and hydrothermal fluid interaction. Neues Jahrbuch für Mineralogie, Abhandlungen, 181: 245-263.

Ślączka A., Unrug R. (1966) Sedimentary structures and petrology of some sandstone members of the Menilite Beds, Carpathians (in Polish with English summary). Rocznik Polskiego Towarzystwa Geologicznego, 36: 155-184.

Turnau-Morawska M., Lydka K. (1954) Petrographic study of the arkose of Kwaczała (in Polish with English summary). Rocznik Polskiego Towarzystwa Geologicznego, 22: 473-494.

Unrug R. (1979) Palinspastic reconstruction of the Carpathian arc before the Neogene tectogenesis. Rocznik Polskiego Towarzystwa Geologicznego, 49: 3-21.

Wdowiarz S. (1949) Structure géologique des Carpates marginales au sud-est de Rzeszów (in Polish with French summary). Biuletyn Państwowego Instytutu Geologicznego, 11: 1-51.

Żachuń M. (1996) Porównanie minerałów ciężkich z arenitów i egzotyków krakowskiej serii piaskowcowej (in Polish). Unpublished MSc thesis. Archive of the Institute of Geological Sciences, Jagiellonian University.

Żgiet J. (1963) Wstepna charakterystyka sedymentologiczna piaskowców kliwskich. Kwartalnik Geologiczny, 7 (4): 715-716.

Žáček V., Sulovský P. (2005) The dyke swarm of fractionated tourmaline-bearing leucogranite and its link to the Vydra Pluton (Moldanubian Batholite), Šumava Mts., Czech Republic. Journal of Czech Geological Society, 50: 10-118. 